\title{
ANALISIS PEST TERHADAP HAMBATAN DAN PELUANG INVESTASI ASING DI KABUPATEN BIREUEN PROVINSI ACEH
}

\author{
Fauzi $^{1}$; Jumhuri ${ }^{2}$ \\ ${ }^{1}$ Dosen Program Studi Hubungan Internasional Fakultas Ilmu Sosial dan Ilmu Politik Universitas Almuslim \\ ${ }^{2}$ Alumni Program Studi Hubungan Internasional Fakultas Ilmu Sosial dan Ilmu Politik Universitas Almuslim \\ Email: fauzi.s.ip.ma@gmail.com, georgemurey81@gmail.com
}

Diterima 25 Mei 2021/Disetujui 5 Juni 2021

\begin{abstract}
ABSTRAK
Penelitian ini bertujuan untuk mengetahui hambatan dan peluang investasi asing di Kabupaten Bireuen Provinsi Aceh melalui analisis PEST. Penelitian ini menggunakan pendekatan kualitatif, yaitu jenis penyelidikan yang bertujuan untuk memahami peranan kelompok atau interaksi pada situasi sosial tertentu. Metode penelitian yang digunakan untuk menjawab hambatan dan peluang investasi asing di Kabupaten Bireuen adalah metode kualitatif yang bersumber dari hasil wawancara, observasi dan data sekunder dari internet, buku dan jurnal. Teori dan konsep yang digunakan dalam penelitian adalah teori Foreign Direct Investment (FDI) dan analisis PEST (Politik, Ekonomi, Sosial dan Teknologi). Konsep ini digunakan untuk menelaah hambatan investasi asing di Kabupaten Bireuen. Adapun analisis peluang, menggunakan peluang di lingkup politik dan ekonomi. Berdasarkan hasil dan pembahasan penelitian dapat disimpulkan bahwa terdapat peluang yang cukup besar untuk terciptanya investasi asing di Bireuen. Adapun hambatan investasi asing di Kabupaten Bireuen terdapat pada koordinasi kebijakan antara pemerintah pusat, provinsi dan Kabupaten Bireuen.
\end{abstract}

Kata kunci: analisis PEST, hambatan dan peluang, investasi asing

\section{PENDAHULUAN}

Provinsi Aceh sebagai salah satu daerah yang diberikan hak istimewa otonomi khusus, selayaknya dapat memanfaatkan amanah yang tertera pada UUPM No 25 Tahun 2007 untuk meningkatkan daya saing pertumbuhan ekonomi secara nasional maupun internasional. Terlebih, melalui kesepakatan MoU Helsinki yang melahirkan UU No. 11 Tahun 2006 tentang Pemerintahan Aceh (UUPA), Ruang Investasi dan PMA di Aceh sangat terbuka lebar. Provinsi Aceh medapatkan kewenangan khusus menjalin hubungan kerjasama (termasuk investasi) dengan lembaga atau badan luar negeri yang dilakukan secara mandiri kecuali masalah pertahanan dan keamanan (Rahmad, Said, 2014). Bahkan, Pasal 166 UUPA menegaskan pemerintah Aceh memberikan kemudahan bagi para investor berupa fasilitas keringan pajak, pembebasan bea masuk, pembebasan pajak dalam rangka impor barang modal dan bahan baku ke Aceh serta ekspor barang jadi dari Aceh, fasilitas investasi, dan lainny. Begitu juga dalam hal pertanahan, pemerintah Aceh berwenang memberikan hak guna bangunan dan usaha bagi penanaman modal dalam negeri dan penanaman modal asing sesuai dengan norma, standar, dan prosedur yang berlaku (Pasal 214 ayat 1, 2 dan 3 UU No. 11 Tahun 2006 tentang Pemerintahan Aceh).

Namun, UUPA khususnya pasal 165 ayat 2 mengalami benturan kepentingan dengan UUPM dalam hal kewenangan pengelolaan investasi asing. Undang-undang No. 25 Tahun 2007 menyatakan bahwa penanaman modal asing merupakan kewenangan pemerintah pusat dalam menarik investor asing dari negara lainnya. Hal ini dikarenakan pelaksanaan permodalan asing dilakukan dengan perjanjian antara negara Indonesia dan negara lain yang ingin menanamkan investasi di Indonesia. Sebaliknya, Pasal 165 ayat (2), UU No. 11 Tahun 2006 menyebutkan; dalam permodalan asing dan menarik investor asing, merupakan kewenangan Pemerintah Aceh. Sama halnya dalam azas peraturan perundangundangan dikenal ketentuan "Aturan hukum yang baru menyisihkan aturan hukum yang lama, aturan hukum yang tinggi mengalahkan aturan hukum yang rendah dan aturan hukum yang khusus menyampingkan aturan hukum yang umum" (Shaleh, M., 2019). 
Laporan Dinas Penanaman Modal dan Pelayanan Terpadu Satu Pintu (DPMPTSP) Aceh tahun 2019 menunjukkan bahwa Kabupaten Singkil dan Bireuen tidak termasuk dalam realisasi PMA Provinsi Aceh. Upaya pemerintah Bireuen dalam mendorong masuknya investor asing telah dilakukan dengan penyedian $640 \mathrm{Ha}$ lahan yang dapat diberdayakan oleh investor dalam negeri maupun luar negeri untuk mendirikan pabrik dan pemanfaatan lain di Kabupaten Bireuen. Bahkan, Seperti dilansir dari www.republika.co.id, pada tahun 2015 dimasa kepemimpinan H.Ruslan M Daud, salah satu perusahaan yang hampir melakukan investasi di Bireuen adalah CJ Feed Indonesia dari Korea Selatan (Zuriya, Nidia, 2015). Namun, sampai tahun 2019, belum ada kepastian terhadap kerjasama investasi yang dilakukan perusahaan Korea Selatan tersebut di Bireuen dan tidak ada aktifitas PMA di Bireuen.

Melihat potensi dan sejarah Kabupaten Bireuen, realisasi PMA sangat mungkin dilaksanakan melalui pemanfaatan sumber daya dan letak strategis yang dimiliki daerah ini. Adapun sektor yang menjadi unggulan Kabupaten Bireuen adalah sektor perikanan, pertanian, perkebunan dan sektor pariwisata (https://dpmptsp.bireuenkab.go.id). Sehingga, dengan melihat letak strategis dan potensi sumber daya yang dimiliki Bireuen, maka penyelenggaraan PMA di kabupaten ini sangat mungkin dilaksanakan.

\section{METODE PENELITIAN}

Penelitian ini menggunakan pendekatan kualitatif, yaitu jenis penyelidikan yang bertujuan untuk memahami peranan kelompok atau interaksi pada situasi sosial tertentu. Metode penelitian yang digunakan untuk menjawab hambatan dan peluang investasi asing di Kabupaten Bireuen adalah metode kualitatif yang bersumber dari hasil wawancara, observasi dan data sekunder dari internet, buku dan jurnal. Teori dan konsep yang digunakan dalam penelitian adalah teori Foreign Direct Investment (FDI) dan analisis PEST (Politik, Ekonomi, Sosial dan Teknologi). Konsep ini digunakan untuk menelaah hambatan investasi asing di Kabupaten Bireuen. Adapun analisis peluang, menggunakan peluang di lingkup politik dan ekonomi.

\section{HASIL DAN PEMBAHASAN}

\section{Analisa PEST (Political, Economy, Socio Cultural, and Technology)}

Analisa PEST pertama kali diperkenalkan oleh Francis J Aquilar (1967) dalam bukunya "Scanning the Business Environment", menjelaskan bahwa untuk memahami lingkungan bisnis dan perdagangan, maka faktor ekonomi, teknikal, politik dan sosial (ETPS) berpengaruh besar dalam menentukan strategi manajemen guna menghadapi perubahan serta dinamika lingkungan bisnis dan perdagangan. Lalu, Arnold Brown dari Institute of Life Insurance mengganti ETPS dengan sebutan STEP (Strategic Trend Evaluation Process) sebagai langkah mengorganisir hasil dari penelusuran lingkungan bisnis dan perdagangan (Veronica Sillinevicha \& Kristine Kallinina, 2017).

Maka, analisa PEST adalah alat analisa yang digunakan perusahaan, instansi, lembaga dan organisasi untuk memahami faktor eksternal yang mempengaruhi penentuan kebijakan dalam perilaku bisnis dan perdagangan. Tanya Sammut-Bonnici \& D Galea (2015), menyebutkan analisa PEST digunakan untuk memahami resiko strategis dalam mengidentifikasi perubahan dan efek lingkungan makro eksternal pada posisi kompetitif perusahaan. Lingkungan eksternal terdiri dari variabel yang ada di luar kendali PILO. Sehingga perlu analisis untuk menyelaraskan strategi yang diambil PILO. RIC Centre menyatakan analisa PEST berbeda dengan analisa SWOT (Strengths, Weaknesses, Opportunities, Treaths). Jika SWOT menitikberatkan pada analisa sisi internal sebuah unit, maka PEST menganalisa faktor eksternal yang secara dinamik mengalami perubahan (https://riccentre.ca/).

Terkait PMA Bireuen, analisa PEST digunakan untuk menelaah situasi hambatan yang dialami Bireuen dalam aktifitas PMA. Sehingga, unsur yang terdapat dalam PEST perlu dikaji lebih lanjut 
untuk kebutuhan analisis hambatan dan peluang PMA Bireuen. Alat analisa PEST mengidentifikasi peluang investasi asing di Bireuen, sehingga memungkinkan pelaksanaan aktifitas PMA Bireuen diimplementasikan secara baik. Pemanfaatan unsur PEST guna mengidentifikasi faktor eksternal yang dibutuhkan untuk mendorong PMA Bireuen, berupa: 1) penentuan investor asing yang diundang memasuki PMA Bireuen sesuai arah kebijakan dan potensi sumber daya Bireuen, 2) penentuan prioritas potensi sumber daya yang dibutuhkan investor asing sehingga terjalin kerjasama PMA di Bireuen, 3) penentuan strategi manajemen Bireuen dalam mendorong pemberlakuan PMA Bireuen, 4) penerapan legislasi kemudahan birokrasi perizinan PMA bagi investor asing, dan 5) rekayasa sosial kultural masyarakat Bireuen dalam menghadapi pelaksanaan PMA Bireuen.

\section{Analisis Hambatan Investasi Asing di Kabupaten Bireuen}

\section{Hambatan dalam Sektor Politik}

Karakter Bireuen sebagai host country diberlakukannya investasi asing dalam analisa PEST termasuk tipologi subnasional. Sehingga, kebijakan dalam menerapkan PMA ditentukan oleh dinamika kebijakan politis pada tingkat supra nasional secara umum dan tingkat nasional secara khusus. Maka, untuk memahami hambatan yang dihadapi Bireuen dalam melaksanakan aktifitas PMA, perlu dipahami terlebih hambatan yang menyebabkan investasi asing pada tingkat nasional dan provinsi. Adapun 4 unsur penting dalam menganalisa hambatan PMA di Bireuen pada sektor politik, yaitu:

\section{Kebijakan Pemerintah tentang PMA}

Implementasi terhadap aturan yang telah ditetapkan, PMA Aceh belum menyentuh keseluruhan tingkat kabupaten yang ada di Aceh. Hal ini disebabkan oleh tumpang tindih implementasi kebijakan antara pemerintah pusat dan daerah. Sehingga, PMA yang berlaku di Bireuen hanya ada jika ada instruksi dari pemerintah pusat atau pengelolaan langsung oleh pemerintah pusat. Hal ini dipertegas dari pernyataan kepala Bappeda Bireuen, Muslim M.Si, yang menyatakan:

"Sampai saat ini, PMA di Bireuen tidak ada pelaksanaanya yang dikelola secara langsung oleh PEMDA Bireuen. pengelolaan masih dilakukan secara terpusat (nasional)”. (wawancara tanggal 16 Juli 2020).

Maka, terdapat misinterpretasi terhadap pengelolaan PMA antara pemerintah pusat, provinsi dan kabupaten yang berakibat terhadap nihilnya aktifitas PMA di Bireuen. Sistem birokrasi terpusat dalam pengelolaan PMA di Bireuen sebagai bagian dari daerah otonomi khusus, menghambat investor asing dalam menanamkan modalnya. Pola birokrasi di Indonesia menggunakan pola Parkinson dan Orwell. Pola birokrasi Parkinson mengarah kepada tidak terkendalinya pertumbuhan jumlah personil dan pemekaran struktural. Sedangkan pola birokrasi Orwell menjelaskan tentang proses perluasan kekuasaaan pemerintah untuk mengontrol kegiatan ekonomi, politik dan sosial dengan peraturan, regulasi, bahkan dengan paksaan (Hans Dieter Evers \& Tilman Schiel, 1990).

Akibat peraturan yang terpusat dalam pengelolaan PMA di Bireuen, maka tidak ditemukan lembaga asing di kabupaten ini. Keberadaan lembaga asing hanya terjadi masa tsunami Aceh. Kehadiran lembaga asing diperlukan di Bireuen melihat dampak peningkatan perekonomian masyarakat yang mengalami transfer economic management knowledge dari lembaga asing tersebut masa tsunami. Hal ini dipertegas dari pernyataan kepala Bappeda Bireuen, Muslim M.Si, yang menyatakan:

"Tidak ada lembaga asing di Bireuen, kalau dulu pada masa tsunami, banyak. Hari ini tidak ada lembaga asing di Bireuen. Aturan yang mengatur keberadaan lembaga asing pun tidak ada pada tingkat daerah. Paling tidak kalau ada lembaga asing di Bireuen, mereka harus ke KESBANGPOL menggunakan aturan nasional tentang keberadaan orang asing di daerah". (wawancara tanggal 16 Juli 2020).

Oleh karena itu, keberadaan lembaga asing di Bireuen menjadi penting demi terciptanya iklim investasi melalui kerjasama yang dimanfaatkan oleh pemerintah daerah dengan negara asal lembaga asing tersebut. Sehingga, dibutuhkan aturan yang diberlakukan pada tingkat kabupaten/kota yang mengatur tentang kerjasama dan penempatan lembaga asing sebagai wadah menunjang aktifitas PMA. 


\section{Perencanaan dan Perizinan}

Pada konsep Owell, kabupaten/kota hanya dijadikan wadah perluasaan kekuasaan pemerintah pusat termasuk dalam permasalahan pengelolaan, perencanaan dan perizinan atas aktifitas PMA. Kebijakan kabupaten/kota sejalan dengan peraturan dan ketentuan yang telah ditentukan pemerintahan diatasnya. Akibatnya, perencanaan pada tingkat kabupaten menyesuaikan dengan arah ketentuan dan kebijakan yang sedang atau akan dijalankan koordinat lembaga diatasnya. Artinya, perencanaan jangka menengah atau jangka panjang kabupaten/kota yang akan dituangkan dalam Rancangan Perencanaan Jangka Menengah (RPJM) mengikuti RPJM yang telah ditentukan baik pada tingkat provinsi maupun nasional. Hal ini sesuai dengan yang disampaikan kepala BAPPEDA Bireuen, Muslim, M.Si, bahwa:

"BAPPEDA hanya pejabat lokal atau regional sehingga Bireuen tidak membuat suatu planning/perencanaan untuk mengundang orang asing, lembaga asing, dan perusahaan asing. Sampai saat ini belum ada rencana terkait hal tersebut". (wawancara tanggal 16 Juli 2020).

Kewenangan BAPPEDA Bireuen hanya sebatas wadah perluasan kebijakan pemerintah pusat atau provinsi, termasuk perencanaan implementasi kebijakan permodalan asing. Jika hal ini berlanjut, berdampak pada terhambatnya pengelolaan PMA di Bireuen. Bahkan, pemerintah Bireuen tidak berkuasa penuh mengelola aktifitas PMA yang berlangsung. Tekanan dan garis koordinasi yang kaku dan menunggu instruksi pemerintah pusat atau provinsi berdampak terhadap inisiasi perencanaan investasi asing di Bireuen. Bahkan sampai 2022, RPJM BAPPEDA Bireuen tidak menyinggung PMA. Hal ini dipertegas oleh kepala Bappeda Bireuen, Muslim M.Si, yang menyatakan:

"Sampai hari ini, BAPPEDA Bireuen sampai tahun 2022 belum ada RPJM yang mengarah pada PMA. Masih terfokus untuk memperkuatkan kebutuhan daripada lokal”. (wawancara tanggal 16 Juli 2020).

Ketidakhadiran PMA pada RPJM BAPPEDA Bireuen menyebabkan perizinan atas aktifitas PMA belum dapat diberlakukan kecuali atas dasar instruksi dari pemerintah pusat maupun pemerintah provinsi. Sehingga, permasalahan perencanaan dan perizinan PMA di Bireuen terhambat karena hirarki kekuasaan yang berlaku dalam sistem pemerintahan di Indonesia.

\section{Stabilitas Politik di Kabupaten Bireuen}

Setelah \pm 15 tahun, Gerakan Aceh Merdeka (GAM) menandatangani perjanjian damai dengan Indonesia, seyogyanya kondisi keamanan untuk menarik investor dapat dilakukan. Terlebih prioritas program pemerintah setelah perdamaian berlangsung adalah pembangunan perekenomian Aceh untuk meningkatkan kesejahteraan masyarakat. Namun, prioritas pemerintah Aceh untuk meningkatkan stabilitas ekonomi masyarakat Aceh berjalan lambat. Hambatan peningkatan perekonomian Aceh terlihat dari minimnya investor asing yang menanamkan modalnya di Aceh, seperti laporan Dinas Penanaman Modal dan Pelayanan Terpadu Satu Pintu (DPMPTSP) Aceh tahun 2019. Bahkan, Bireuen sebagai kota strategis dalam pengembangan PMA mengalami hasil nihil dalam aktifitas PMA.

Jika diperhatikan lebih lanjut, instabilitas politik di Bireuen hanya terjadi pada masa kampanye politik, yang dilakukan partai politik untuk meraup suara agar dapat memenangkan konstetasi politik kekuasaan. Oleh karena itu, stabilitas politik di Kabupaten Bireuen hanya bersifat eventual, yaitu kekacauan politik hanya terjadi pada masa kampanye perebutan kekuasaan dimasa pemilihan umum.

\section{Transparansi dan Kontrol atas Korupsi}

Pada tahun 2019, kejaksaan Bireuen mengeksekusi 1 kepala sekolah SMKN 1 Bireuen dan 3 aparatur sipil negara (ASN) yang melakukan tindakan korupsi atas penyimpangan dana bantuan SMK Mandiri serta penyimpangan sisa dana uang persedian (UP) tahun 2011 pada dinas pengelolaan kekayaan dan keuangan daerah Kab. Bireuen (https://aceh.tribunnews.com). Selain itu, pada tahun 2020, korupsi dilakukan oleh oknum geuchik yang melakukan penyimpangan anggaran dana desa dan merugikan negara sebesar 296 juta rupiah (https://www.ajnn.net). Lalu, pada Juni 2020, Aliansi Mahasiswa dan 
Pemuda (AMP) Bireuen mendesak pemberlakuan hukum atas tindak pidana korupsi yang dilakukan 13 ASN di Kab. Bireuen (https://www.ajnn.net).

\section{Hambatan dalam Sektor Ekonomi}

\section{Tahapan Siklus Bisnis}

Jika melihat kondisi Bireuen secara khusus dan Aceh secara umum, maka pertumbuhan ekonomi di daerah ini masih berada pada fase recovery pasca perjanjian MoU Helsinki yang menandakan berakhirnya konflik antara GAM dan pemerintah Indonesia serta pasca tragedi tsunami. Namun, masa recovery ekonomi mengalami fase yang lambat dalam penanganannya. Penurunan keuntungan dan kesejahteraan ekonomi dirasakan masyarakat pedagang dan pengusaha di Kab. Bireuen. Penerapan kebijakan pemerintah khususnya pajak yang harus ditanggung pengusaha memberatkannya. Sitti seorang pengusaha bidang perikanan menyebutkan bahwa:

"Dalam 2 tahun ini, keuntungan kami sangat menurun drastis terlebih adanya virus corona. Sebelum virus corona pun, demikian adanya. Kami tidak sanggup memenuhi ketentuan pajak dan biaya pengiriman barang yang tinggi”. (wawancara pada tanggal 02 Agustus 2020).

Melihat fase siklus bisnis di Kab. Bireuen, peneliti berpendapat bahwa pemerintah Kab. Bireuen harus mengambil langkah yang cepat dalam memasuki fase ekspansi bisnis untuk meningkatkan lapangan kerja serta meminimalisir tingkat pengangguran di Kab. Bireuen. Salah satu upaya yang bisa dilakukan adalah melaksanakan rancangan perencanaan untuk menarik investor baik dalam negeri maupun luar negeri. Hal yang perlu dikembangkan pada tahapan awal adalah melakukan pemetaan terhadap potensi SDA yang dimungkinkan untuk menarik para investor. Selanjutnya, perlu kerjasama dengan konsultan survei dari lembaga, akademisi maupun tim ahli dari pemerintah daerah.

\section{Pertumbuhan Ekonomi}

Pertumbuhan ekonomi di Kab. Bireuen mengalami pertumbuhan yang sangat baik. Artinya, walaupun tingkat pengangguran di Kab. Bireuen meningkat, tetapi pertumbuhan ekonominya meningkat setiap tahunnya. Hal ini diyakini Dailami, S.Hut disebabkan meningkatnya geliat UMKM di Kab. Bireuen sebagai bagian dari program prioritas nasional dan daerah untuk meningkatkan pertumbuhan ekonomi. "Pertumbuhan ekonomi Bireuen terus meningkat setiap tahunnya, terutama pada sektor UMKM sebagai bagian dari program prioritas pengembangan ekonomi secara nasional. Geliatnya semakin baik setiap bulannya". (wawancara dilakukan pada tanggal 03 Agustus 2020 ).

Maka, pertumbuhan ekonomi di Kab. Bireuen meningkat secara sektoral yang menjadikan hambatan ketenagakerjaan (pengangguran) tidak mempengaruhi geliat pertumbuhan ekonomi Bireuen. Sehingga pertumbuhan ekonomi yang meningkat di Kab. Bireuen bisa dijadikan acuan guna menarik investor asing untuk menanamkan modalnya di Bireuen. Tindakan ini tidak hanya berdampak kepada makin meningkatnya pertumbuhan ekonomi Bireuen, namun mengurangi permasalahan ketenagakerjaan (pengangguran) yang dapat ditekan karena masuknya penambahan penanaman modal.

\section{Hambatan dalam Sektor Sosial Budaya}

Pengembangan budaya di Kab. Bireuen telah memberikan arah bagi perwujudan identitas daerah sebagai bagian dari nilai-nilai luhur budaya bangsa. Selain itu, pengembangan budaya di Kab. Bireuen telah menciptakan iklim kondusif dan harmonis, sehingga nilai-nilai kearifan lokal mampu merespon secara positif dan produktif akan modernisasi sejalan dengan nilai dan norma yang ada di masyarakat. Kebijakan pengembangan budaya di Kab. Bireuen adalah melalui nilai budaya, pengelolaan keragaman dan kekayaan budaya dengan cara meningkatkan fungsi dan mengembangkan sarana pendukung kehidupan adat, tradisi, kegiatan seni budaya serta melestarikan warisan seni dan budaya masyarakat Bireuen. Pengembangan nilai budaya masyarakat Bireuen dilakukan dengan memelihara aset budaya masyarakat, seperti kekayaan budaya, sejarah dan simbol kebanggaan masyarakat Bireuen, sehingga kehidupan budaya masyarakatnya berjalan dengan kondusif dan harmonis. 


\section{Hambatan dalam Sektor Teknologi}

Setiap perkembangan dan kemajuan teknologi akan disertai dengan perubahan substansial dalam kehidupan manusia, baik yang berdampak positif maupun negatif. Sehingga masyarakat yang berperilaku dinamis perlu dipersiapkan untuk meningkatkan kapasitas dan kapabilitas dalam menyerap dan menerapkan penggunaan teknologi. Samuel Koenig menyebutkan bahwa perubahan sosial terlihat pada modifikasi yang terjadi dalam pola kehidupan manusia. Karl Marx mengemukakan bahwa perubahan sosial merupakan perubahan-perubahan yang terjadi karena perkembangan teknologi atau kekuatan produktif serta hubungan antara kelas-kelas sosial yang berubah.

Straubhaar., LaRose (dalam Harun., Ardianto: 2013) menyatakan transisi terhadap masyarakat informasi adalah sebuah percepatan, karena perubahannya sangat luar biasa dalam teknologi. Harun., Ardianto menjelaskan bahwa dilingkungan masyarakat tradisional ilmu, pengetahuan yang digunakan sebagai dasar berpikir relatif sederhana dan paradigma ilmiahnya tampak kaku disertai pendekatan yang sederhana. Sebaliknya, di lingkungan masyarakat modern, instrumen berpikir yang digunakan sudah memanfaatkan teori baru dan perkembangan ilmu pengetahuan yang canggih dan spesialistik.

Penjelasan di atas adalah bagian tidak terpisahkan dari perubahan sosial yang terjadi di Kab. Bireuen, yaitu masyarakatnya mengalami adaptasi perubahan sosial yang peka terhadap perkembangan teknologi. Jika diperhatikan dalam kehidupan sosial, khususnya di warung kopi Bireuen. alat teknologi menjadi kebutuhan mendasar dalam kehidupan masyarakat. Adaptasi atas kehidupan sosial baru menggunakan teknologi berdampak pada penerapan kebijakan pro dan kontra aparatur desa.

Pada kebijakan kontra terhadap akses teknologi, terjadi di gampong Curee Baroh Kec. Simpang Mamplam Bireuen yang memberikan himbauan melarang bagi warung kopi di sekitar kampung untuk menyediakan fasilitas wifi. Kebijakan tersebut diambil sebagai reaksi atas dampak negatif internet bagi anak-anak desa yang melalaikan kewajiban belajar dan bersekolah (https://www.ajnn.net/). Sedangkan bagi yang pro terhadap pemanfaatan teknologi tidak mempermasalahkan akses internet bagi masyarakat. kontrol atas pemanfaatan internet ditanggungjawabkan kepada individu. Sehingga, pemanfaatan teknologi oleh masyarakat Bireuen menjadi satu kesatuan pada kebutuhan hidup yang tidak dapat dipisahkan. Artinya, masyarakat Bireuen telah menjadi bagian dari masyarakat modern yang tidak mempermasalahkan dan telah terbiasa memanfaatkan teknologi.

\section{Analisis Peluang Investasi Asing di Kabupaten Bireuen}

\section{Peluang/Potensi Pada Sektor Politik}

Sebagai daerah yang memiliki letak geografis serta geopolitik yang strategis, Bireuen menjadi kabupaten yang diprioritaskan terhadap pengembangan PMA di kabupaten. Posisi Bireuen pada lautan selat malaka memberikan kemudahan akses transportasi laut bagi investor asing melakukan aktifitas ekonomi. Letak geografis di jalur transportasi antarkabupaten di Provinsi Aceh menyebabkan Kab. Bireuen berkembang cepat. Letak Kab. Bireuen yang berbatasan dengan Kab. Bener Meriah, Pidie Jaya dan Aceh Utara memberikan keuntungan bagi perekonomian masyarakat dan investor.

Sebagai pendiri lembaga birokratis yang menangani secara langsung PMA, Bireuen memiliki dinas PMA yang berdiri sendiri sehingga koordinasi serta penanganan perencanaan dan pengelolaan PMA dapat dilakukan pada tahun selanjutnya. Adanya DPMPTSP PMA di Kab. Bireuen, kewenangan terhadap rencana PMA di Kab. Bireuen dapat dilakukan secara baik.

"DPMPTSP PMA Bireuen merupakan dinas baru yang baru efektif berjalan pada bulan Februari 2020. Saat ini kami telah berupaya membuat buku investasi dalam bentuk buku promosi yang disebut buku potensi pengembangan investasi di Kabupaten Bireuen". (Wawancara pada tanggal 20 Juli 2020).

\section{Peluang/Potensi Pada Sektor Ekonomi}

Secara ekonomi, Bireuen berpotensi sangat besar pada beberapa sektor yang menjadi unggulan. Pada sektor pertanian, tanaman pangan dan holtikultura diarahkan sebagai peningkatan ketahanan pangan 
guna mencukupi kebutuhan pokok serta pengembangan agrobisnis yang menghasilkan produk pertanian berdaya saing tinggi, guna meningkatkan pendapatan dan kesejahteraan petani. Potensi tanaman jagung di Bireuen mampu menarik minat pemerintahan pusat Indonesia untuk menjadikan Bireuen sebagai bagian dari pilot project program Grand Design Alternative Development (GDAD) yang merupakan program Kementerian Pertanian yang bekerjasama dengan Badan Narkotika Nasional (BNN). Melalui program ini, Bireuen dijadikan sebagai daerah pengembangan jagung jenis hibrida yang menjadi penyumbang swasembada jagung di Indonesia (https://bnn.go.id/). Muliady, ketua di DPMPTSP PMA Bireuen, mengatakan bahwa:

"Secara spesifik potensi pertanian yang dimiliki Bireuen adalah Jagung yang sempat menjadi minat bagi pengusaha dari Malaysia karena kebutuhan yang besar”. (wawancara pada 20 Juli 2020).

Selain potensi tanaman jagung, Bireuen merupakan daerah penghasil jeruk bali (Buah Giri) yang turut menjadi ciri khas bagi daerah ini. Buah Giri yang dimiliki Bireuen dijadikan salah satu potensi produk unggulan pada komoditi ekspor. Selain karena Buah Giri telah menjadi buah yang ditanam turun temurun dan bernilai historis secara khusus bagi masyarakat Bireuen, Buah Giri memiliki khasiat yang baik bagi kesehatan, terutama penyakit jantung. Pada segi potensi perikanan, Bireuen sebagai daerah pesisir, memiliki potensi perikanan yang menjadi daya tarik bagi investor asing. Penulis sendiri pernah bergerak pada bidang perikanan dengan melakukan ekspor ikan kerapu ke Malaysia dan Thailand. Sayangnya, potensi ikan kerapu di Bireuen khususnya dalam aspek pembibitan, belum menjadi prioritas pemerintah Kab. Bireuen. Aktifitas ekspor ikan kerapu hanya dilakukan pengusaha tertentu yang terkendala dalam hal perizinan dan penyediaan kebutuhan besar pasar Internasional.

Potensi SDA pada sektor ekonomi yang dijadikan komoditi menarik investor asing adalah ketersediaan wisata alam yang belum dikelola secara baik dan professional. Salah satunya pantai Peuneulet di Desa Peuneulet, Baroh Kec. Simpang Mamplam. Pantai ini menyajikan panorama alam yang sangat indah serta ombak yang besar dan mampu menarik minat wisatawan asing untuk melakukan olahraga surfing. Potensi wisata lainnya yang dimanfaatkan sebagai bagian dari promosi Bireuen sebagai daerah PMA adalah situs budaya dan sejarah seperti Rumah Tgk.Chik Di Awe Geutah, makam Habib Bugak dan makam syuhada lapan. Wisata sejarah ini dimanfaatkan untuk menarik wisatawan dari negara lain yang memiliki ikatan sejarah dengan tokoh di atas.

\section{SIMPULAN}

Berdasarkan hasil dan pembahasan penelitian dapat disimpulkan bahwa sebagai salah satu kabupaten di Provinsi Aceh, Bireuen secara politik berpotensi sebagai daerah target pemberlakuan PMA di Aceh. Letak geografis dan geopolitik yang mendukung dijadikan alasan pemerintah Bireuen untuk mencanangkan RPJM tentang PMA. Namun, Bireuen belum memiliki RPJM secara khusus tentang PMA. Hal ini menjadi faktor penghambat bagi Bireuen dalam pemberlakuan PMA. Selain itu, stabilitas politik yang semakin baik di Kabupaten Bireuen merupakan syarat lain menarik investor asing untuk menanamkan modal di Bireuen. Sehingga, instabilitas politik di Bireuen terjadi ketika pergelaran PEMILU diadakan dan wajar pada setiap pesta demokrasi bahkan terjadi di negara lain.

Dari segi ekonomi, potensi yang dimiliki Bireuen pada sektor perikanan, pertanian, perkebunan dan pariwisata perlu pembenahan inovasi untuk menarik para investor. Namun pada sektor ekonomi, hambatan PMA Bireuen tidak menunjukkan dampak negatif. Artinya, sektor ekonomi di Bireuen termasuk sebagai daerah yang pertumbuhan ekonominya baik dan dapat dijadikan nilai jual Kabupaten Bireuen dalam aktifitas PMA. Pemerintah Bireuen sepatutnya mengklasifikasi potensi sumber daya alam Bireuen yang dapat menarik minat investor dalam aktifitas PMA. Secara sosial, masyarakat Bireuen mengalami perubahan dan terbuka terhadap budaya dari luar daerah maupun internasional, selama budaya tersebut masih menghargai kearifan lokal yang berlaku di Bireuen. 
Keterbukaan serta modernitas masyarakat Bireuen memberikan kenyamanan serta rasa aman bagi investor asing untuk menanamkan modal di Bireuen. Oleh karena itu, terdapat peluang yang cukup besar untuk terciptanya investasi asing di Bireuen. Adapun hambatan investasi asing di Kabupaten Bireuen terdapat pada koordinasi kebijakan antara pemerintah pusat, provinsi dan Kabupaten Bireuen.

\section{REFERENSI}

Dieter E.H., Schiel, Tilman. 1990. Kelompok-kelompok Strategis: Studi Perbandingan tentang Negara, Birokrasi dan Pembentukan Kelas di Dunia Ketiga. Jakarta: Yayasan Obor Indonesia.

Dokumen RPJM $2015 . \quad$ Sumber: http://sippa.ciptakarya.pu.go.id/sippa_online/ws_file/dokumen/rpi2jm/DOCRPIJM_150840413 7BAB_II.pdf. diakses tanggal 10 Agustus 2020.

Gampong di Bireuen Larang Warkop Sediakan Akses Internet. Sumber: https://www.ajnn.net/news/gampong-di-bireuen-larang-warkop-sediakan-aksesinternet/index.html. diakses tanggal 13 Agustus 2020.

Harun., Ardianto. 2013. Komunikasi Pembangunan dan Perubahan Sosial. Jakarta: Raja Grafindo Persada.

Kasus Korupsi Dana Desa di Bireuen, Jaksa sudah Periksa 23 Saksi. Sumber: https://www.ajnn.net/news/kasus-korupsi-dana-desa-di-bireun-jaksa-sudah-periksa-23saksi/index.html. diakses tanggal 16 Agustus 2020.

Kejari Bireuen Eksekusi Empat Terpidana Korupsi. Sumber: https://aceh.tribunnews.com/2019/12/11/kejari-bireuen-eksekusi-empat-terpidana-korupsi. diakses tanggal 16 Agustus 2020.

Peluang Investasi di Bireuen; Potensi dan Keunggulan Kabupaten Bireuen. Sumber: https://dpmptsp.bireuenkab.go.id/peluang-investasi/. diakses tanggal 21 Juli 2020.

Pengembangan Jagung Hibrida di Lahan Seluas 11.047 ha di Bireuen Bentuk Sinergi Implementasi GDAD Tahun 2019. Sumber: https://bnn.go.id/pengembangan-jagung-hibrida-lahan-seluas-11047-ha-bireuen/. diakses tanggal 10 Agustus 2020.

Qanun Aceh Nomor 5 Tahun $2018 . \quad$ Sumber: https://peraturan.bkpm.go.id/jdih/userfiles/batang/Qanun_Aceh_Nomor_5_Tahun_2018_tentan g_Penanaman_Modal.pdf. diakses tanggal 21 Juli 2020.

Rahmad, Said R. 2014. Kesiapan Pemerintah Aceh dalam Deregulasi (Qanun Aceh) dan Kebijakan Penanaman Modal.

Sumber: http://acehinstitute.org/wp-content/uploads/2014/10/KESIAPAN_ PEMERINTAH_ ACEH_DALAM_DEREGULASI_QANUN_ACEH _DAN_KEBIJAKAN_PENANAMAN_ MODAL. pdf. diakses tanggal 21 Juli 2020.

RIC Centre. SWOT Analysis and PEST Analysis. Sumber: https://riccentre.ca/wpcontent/uploads/2012/01/Session-1-Takeaways-Guidlines.pdf. diakses tanggal 21 Juli 2020.

Shaleh, M. 2019. Nova Iriansyah dan Kotak Pandora Investasi Aceh. Sumber: https://modusaceh.co/news/nova-iriansyah-dan-kotak-pandora-investasi-aceh/index.html. diakses tanggal 21 Juli 2020.

Sammut-Bonnici, T., Galea, D. 2015. PEST Analysis. Journal Wiley Encyclopedia of Management. Volume 12.

Sillinevicha, Veronica., Kallinina, Kristine. 2017. The Development of The Evaluation System of Factors, Influencing on the Organization for The Prevention of Risks of Its Activity in The Market in Any Field of Activity, Using PEST Analysis. Professional Studies: Theory and Practice. 2017/ 3 (18). Hal. 38-44.

Undang-Undang RI tentang Penanaman Modal No.25 Tahun 2007. Sumber: https://www.bi.go.id/id/tentang-bi/uu-bi/Documents/UU25Tahun2007PenanamanModal.pdf. diunduh tanggal 21 Juli 2020. 